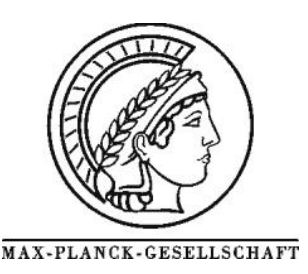

\title{
Structure stabilizing effect of tungsten in mixed molybdenum oxides with $\mathrm{Mo}_{5} \mathrm{O}_{14}$-type structure
}

\author{
E. Rödel ${ }^{\mathrm{a}}$, O. Timpe ${ }^{\mathrm{a}}$, A. Trunschke ${ }^{\mathrm{a}}$, G.A. Zenkovets ${ }^{\mathrm{b}}$, G.N. Kryukova ${ }^{\mathrm{b}}$, R. Schlögl ${ }^{\mathrm{a}}$, T. Ressler ${ }^{\mathrm{c}}$ \\ ${ }^{a}$ Fritz-Haber-Institut der MPG, Department of Inorganic Chemistry, Faradayweg 4-6, D-14195 Berlin, Germany \\ ${ }^{\mathrm{b}}$ Boreskov Institute of Catalysis, Novosibirsk 630090, Russia \\ ${ }^{c}$ Technische Universität Berlin, Institute of Chemistry, Sekr. C2, Strasse des 17. Juni 135, D-10623 Berlin, Germany
}

" Corresponding author: e-mail Thorsten.Ressler@ TU-berlin.de, Tel.: +49 308413 3192; fax: +49 3031421106

Available online 16 May 2007.

\begin{abstract}
Bulk structural properties of single phase crystalline $\left(\mathrm{Mo}_{0.91} \mathrm{~V}_{0.09}\right)_{5} \mathrm{O}_{14}$ and $\left(\mathrm{Mo}_{0.68} \mathrm{~V}_{0.23} \mathrm{~W}_{0.09}\right)_{5} \mathrm{O}_{14}$ materials were investigated using in situ X-ray diffraction and in situ X-ray absorption spectroscopy at three metal edges. Temperature programmed experiments in reducing (propene) and oxidizing (oxygen) atmosphere and isothermal redox experiments at $773 \mathrm{~K}$ revealed differences in the bulk properties of the two phases studied. A structure stabilizing effect of tungsten in $(\mathrm{MoVW})_{5} \mathrm{O}_{14}$ under oxidizing conditions was found. Moreover, tungsten centers in a (MoVW) dioxide material exert a structure-directing effect towards re-oxidation to a $\mathrm{Mo}_{5} \mathrm{O}_{14}$-type structure.
\end{abstract}

Keywords: $\mathrm{Mo}_{5} \mathrm{O}_{14}$-type structure; X-ray diffraction; XAS; Redox properties

\section{Introduction}

Molybdenum containing metal oxide catalysts selectively oxidize propene to acrylic acid. The ability of molybdenum to occur in various coordination geometries gives rise to a high structural diversity of the mixed transition metal oxides. Catalytically active sites in these mixed oxides may be stabilized by characteristic structural motifs induced by the cationic composition [1,2]. Small amounts of $\mathrm{V}$ or $\mathrm{W}$ in Mo oxides may result in the formation of $(\mathrm{MoV})$ oxides and (MoVW) oxides that crystallize in the tetragonal $\mathrm{Mo}_{5} \mathrm{O}_{14}$ structure [3]. This structure has been suggested to represent the motif of the active phase for the selective oxidation of acrolein into acrylic acid [4,5]. The $\mathrm{Mo}_{5} \mathrm{O}_{14}$ structure corresponds to a pentagonal column phase with a narrow phase width and an open structure with five- and six-fold channels parallel to the c-axis [6]. Several possible compositions with various cations stabilizing the $\mathrm{Mo}_{5} \mathrm{O}_{14}$ structure have been described in the literature $[7,8,9,10,11,12,13]$.

Here, $(\mathrm{MoVW})_{5} \mathrm{O}_{14}$ and $(\mathrm{MoV})_{5} \mathrm{O}_{14}$ have been prepared as crystalline single phase materials exhibiting catalytic activity in the selective oxidation of propene [14,23]. In situ X-ray diffraction (XRD) and in situ X-ray absorp- tion spectroscopy (XAS) combined with online gas phase analysis are used to explore the structural evolution of these single phase $\mathrm{Mo}_{5} \mathrm{O}_{14}$-type materials under varying reactive atmospheres. XRD and XAS give access to both the long range order of the materials and the local structure around the metal centers in these mixed oxides.

\section{Experimental}

\subsection{Preparation}

The precursor of the $(\mathrm{MoVW})_{5} \mathrm{O}_{14}$ material was prepared as described previously [14]. Ammonium heptamolybdate $(\mathrm{AHM}) \quad(\mathrm{c}=0.963 \mathrm{~mol} / \mathrm{L})$ and ammonium metatungstate $(\mathrm{AMT})(\mathrm{c}=0.27 \mathrm{~mol} / \mathrm{L})$ were dissolved in bidestilled water at $353 \mathrm{~K} . \mathrm{V}_{2} \mathrm{O}_{5}$ was dissolved in an aqueous solution of $1.93 \mathrm{~mol} / \mathrm{L}$ oxalic acid at $353 \mathrm{~K}$ (vanadyl oxalate aqueous solution $\mathrm{c}=0.379 \mathrm{~mol} / \mathrm{L}$ ). The solutions were mixed in a $2 \mathrm{~L}$ batch and heated to $353 \mathrm{~K}$ for 1 h. After spray-drying of the mixed solutions the resulting material was calcined for $2 \mathrm{~h}$ in synthetic air at $623 \mathrm{~K}$ and the heated for $2 \mathrm{~h}$ in helium at $713 \mathrm{~K}$. The metal content in 
the $(\mathrm{MoVW})_{5} \mathrm{O}_{14}$ phase amounted to $68 \mathrm{~mol}-\% \mathrm{Mo}, 23$ mol- $\% \mathrm{~V}$, and 9 mol- $\% \mathrm{~W}$.

The $(\mathrm{MoV})_{5} \mathrm{O}_{14}$ material was prepared as follows. An aqueous solution of vanadyl oxalate was obtained by dissolving $7.7 \mathrm{mg} \mathrm{V}_{2} \mathrm{O}_{5}$ and $15.9 \mathrm{mg}$ oxalic acid in $132 \mathrm{ml}$ water. The resulting blue solution was mixed with a solution of $200 \mathrm{mg}$ AHM in $500 \mathrm{ml}$ water at $353 \mathrm{~K}$. After stirring at this temperature for $1 \mathrm{~h}$, the solution was spraydried. The spray-dried powder was treated in helium at 773 $\mathrm{K}$ for $4 \mathrm{~h}$ followed by dissolution of impurities in $1 \mathrm{~mol} / \mathrm{L}$ ammonia solution at $313 \mathrm{~K}$ for $5 \mathrm{~min}$. Subsequently, the resulting material was heated in helium to $773 \mathrm{~K}$ for $4 \mathrm{~h}$. The metal content in the $(\mathrm{MoV})_{5} \mathrm{O}_{14}$ phase amounted to 91 mol-\% Mo and 9 mol-\% V.

\subsection{In situ $X$-ray diffraction}

Combined in situ XRD/MS experiments were performed on a STOE Theta/Theta diffractometer (secondary $\mathrm{Si}$ (111) monochromator, $\mathrm{Cu} \mathrm{K}_{\square}$ radiation). $30-80 \mathrm{mg}$ of the powdered $(\mathrm{MoVW})_{5} \mathrm{O}_{14}$ or $(\mathrm{MoV})_{5} \mathrm{O}_{14}$ were used. The diffractometer was equipped with a XRK 900 high temperature cell from Anton Paar. All measurements were conducted under atmospheric pressure in flowing atmosphere at $100 \mathrm{ml} / \mathrm{min}$. The gas phase composition at the cell outlet was analyzed on line with a mass spectrometer (Omnistar, QMS Pfeiffer). Ex situ XRD measurements were performed on a STOE STADI-P diffractometer with a Ge (111) primary monochromator and a position sensitive detector. Phase analysis was performed using the DIFFRAC PLUS evaluation software [15]. Structure refinement was conducted using the TOPAS 3 software package [16] and single crystal structure data from the inorganic crystal structure database (ICSD [17]).

\subsection{In situ X-ray absorption spectroscopy}

XAS measurements were performed in the transmission mode at the Mo K edge (19.999 keV), $\mathrm{W} \mathrm{L}_{\mathrm{III}}(10.204 \mathrm{keV})$ edge, and at the V K edge (5.465 $\mathrm{keV}$ ) at beamline X1 and E4 at the Hamburger Synchrotronstrahlungslabor, HASYLAB, respectively. The experiments were conducted in a flow reactor of $\sim 4 \mathrm{ml}$ volume at atmospheric pressure in $30 \mathrm{ml} / \mathrm{min}$ flowing reactants. The gas phase composition at the cell outlet was analyzed on line with a mass spectrometer (Omnistar, QMS Pfeiffer). $30 \mathrm{mg}$ BN were mixed with about $8 \mathrm{mg}$ sample, ground, and pressed at a force of 1 ton into a pellet of $5 \mathrm{~mm}$ in diameter. The resulting edge jump amounted to $\Delta \mu \sim 1$ at the Mo $\mathrm{K}$ edge, $\Delta \mu \sim 0.2-0.3$ at the $\mathrm{V} \mathrm{K}$ edge, and $\Delta \mu \sim 0.8$ at the $\mathrm{W} \mathrm{L}_{\text {III }}$ edge. Data processing and analysis was performed with the software package WinXAS 3.1 [18]. The photon energy was calibrated to a spectrum of the corresponding metal. First order polynomials were chosen for background subtraction. Third order (Mo K edge) or second order (V K edge, $\mathrm{W}_{\mathrm{LIII}}$ edge) polynomials were used for normalization. Average valences of vanadium were determined from the preedge peak height [19]. The average valence of molybdenum was obtained from analyzing the Mo $\mathrm{K}$ edge position according to a previously reported procedure [20].

\subsection{Reduction and re-oxidation experiments}

The structural evolution of $(\mathrm{MoVW})_{5} \mathrm{O}_{14}$ and $(\mathrm{MoV})_{5} \mathrm{O}_{14}$ was investigated during temperatureprogrammed and isothermal experiments. Temperature-programmed XAS and XRD measurements were conducted in reducing (10\% propene) and oxidizing (20\% oxygen) atmospheres in the temperature range from $300 \mathrm{~K}$ to $773 \mathrm{~K}$. A heating rate of $3 \mathrm{~K} / \mathrm{min}$ (XAS) or $0.4 \mathrm{~K} / \mathrm{min}$ (XRD, average heating rate) was used. Prior to the isothermal redox experiments, $(\mathrm{MoVW})_{5} \mathrm{O}_{14}$ and $(\mathrm{MoV})_{5} \mathrm{O}_{14}$ were heated in helium to $773 \mathrm{~K}$ at a heating rate of $10 \mathrm{~K} / \mathrm{min}$. The structural stability of the materials in helium at $773 \mathrm{~K}$ was confirmed by XRD and XAS. Subsequently, the atmosphere was switched to $10 \%$ propene or $10 \%$ hydrogen at $773 \mathrm{~K}$ and XRD or XAS scans were measured until the sample was completely reduced. The resulting materials were re-oxidized in $20 \%$ oxygen at $773 \mathrm{~K}$ and XRD or XAS scans were measured until complete re-oxidation. In addition, XRD and XAS scans were measured at $300 \mathrm{~K}$ before and after the temperature-programmed and isothermal experiments.

\section{Results}

\subsection{Characterization of (MoVW)5O14 and (MoV)5014}

Phase purity of the $(\mathrm{MoV})_{5} \mathrm{O}_{14}$ and the $(\mathrm{MoVW})_{5} \mathrm{O}_{14}$ materials used was verified by XRD [21]. Lattice constants obtained from the refinement of the tetragonal $\mathrm{Mo}_{5} \mathrm{O}_{14}$ structure (ICSD [27202]) to the experimental XRD pattern are given in Table 1. No detectable amounts of amorphous materials were found in a XRD analysis of a mixture of 50 $\%(\mathrm{MoVW})_{5} \mathrm{O}_{14}$ and $50 \% \alpha-\mathrm{Al}_{2} \mathrm{O}_{3}$ as internal standard. The characteristic XRD pattern of the $\mathrm{Mo}_{5} \mathrm{O}_{14}$ structure is given in Figure 1a. Transmission electron microscopy investigations showed only the $\mathrm{Mo}_{5} \mathrm{O}_{14}$-type structures in $(\mathrm{MoVW})_{5} \mathrm{O}_{14}$ and $(\mathrm{MoV})_{5} \mathrm{O}_{14}$. 
Table 1: Lattice constants from XRD refinement of tetragonal $(\mathrm{MoVW})_{5} \mathrm{O}_{14}$ and $(\mathrm{MoV})_{5} \mathrm{O}_{14}$ based on ICSD [27202]

\begin{tabular}{|l|l|l|}
\hline & $(\mathrm{MoV})_{5} \mathrm{O}_{14}$ & $(\mathrm{MoVW})_{5} \mathrm{O}_{14}$ \\
\hline $\mathrm{a}[\AA]$ & 22.88 & 22.76 \\
\hline $\mathrm{c}[\AA]$ & 4.00 & 3.99 \\
\hline
\end{tabular}
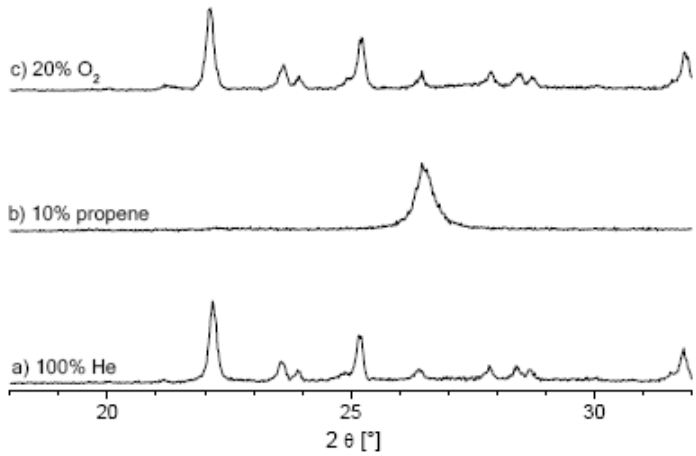

Figure 1: In situ XRD of sample $(\mathrm{MoVW})_{5} \mathrm{O}_{14}$ during redox experiment: heating in helium to $773 \mathrm{~K}$, isothermal at $773 \mathrm{~K}$ reduction in $10 \%$ propene, re-oxidation in $20 \%$ oxygen.
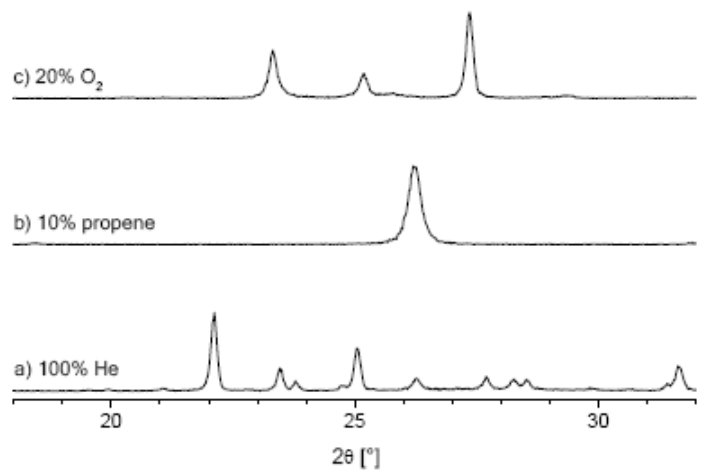

Figure 2: In situ $\mathrm{XRD}$ of $(\mathrm{MoV})_{5} \mathrm{O}_{14}$ during redox experiment: heating of sample in helium to $773 \mathrm{~K}$, isothermal at $773 \mathrm{~K}$ reduction in $10 \%$ propene, re-oxidation in $20 \%$ oxygen.

\subsection{Redox properties of (MoVW)5014 and (MoV)5014}

\section{In situ X-ray diffraction}

The $\mathrm{Mo}_{5} \mathrm{O}_{14}$-type structure of $(\mathrm{MoVW})_{5} \mathrm{O}_{14}$ and $(\mathrm{MoV})_{5} \mathrm{O}_{14}$ was stable during heating in helium to $773 \mathrm{~K}$ (Figure 1a and Figure 2a). Under reducing conditions in 10 $\%$ propene at $773 \mathrm{~K}$, the $(\mathrm{MoV})_{5} \mathrm{O}_{14}$ and $(\mathrm{MoVW})_{5} \mathrm{O}_{14}$ materials were completely transformed into monoclinic $\mathrm{MoO}_{2}$-type structures (Figure $1 \mathrm{~b}$ and Figure 2b). Lattice constants obtained from a refinement of a $\mathrm{MoO}_{2}$ model structure (ICSD [23722]) to the patterns of the $\mathrm{MoO}_{2}$-type phases are given in Table 2. Compared to the (MoVW) dioxide, the lattice constants of the $(\mathrm{MoV})$ dioxide material that contains less vanadium showed an expansion of the aaxis, shortening of the b- and c-axis, and an increased unit cell volume. Upon switching to $20 \%$ oxygen at $773 \mathrm{~K}$, the (MoVW) dioxide was re-oxidized and the resulting oxide exhibited the $\mathrm{Mo}_{5} \mathrm{O}_{14}$-type structure of the initial $(\mathrm{MoVW})_{5} \mathrm{O}_{14}$ material (Figure 1c). Conversely, reoxidation of the (MoV) dioxide in $20 \%$ oxygen at $773 \mathrm{~K}$ resulted in an orthorhombic $\mathrm{MoO}_{3}$-type structure (Figure 2c). No intermediate Mo oxide phases were detectable in the XRD patterns during reduction and re-oxidation.

Temperature-programmed XRD measurements in $10 \%$ propene yielded an onset of reduction of the $(\mathrm{MoVW})_{5} \mathrm{O}_{14}$ material to a monoclinic $\mathrm{MoO}_{2}$-type structure at $723 \mathrm{~K}$. Conversely, reduction of $(\mathrm{MoV})_{5} \mathrm{O}_{14}$ to a monoclinic $\mathrm{MoO}_{2}$-type structure started already at $673 \mathrm{~K}$. During temperature programmed thermal treatment of $(\mathrm{MoVW})_{5} \mathrm{O}_{14}$ in $20 \%$ oxygen, the $\mathrm{Mo}_{5} \mathrm{O}_{14}$-type structure was stable up to $773 \mathrm{~K}$. No oxidation or decomposition was observed. Conversely, the $\mathrm{Mo}_{5} \mathrm{O}_{14}$-type structure of $(\mathrm{MoV})_{5} \mathrm{O}_{14}$ was stable during treatment in $20 \%$ oxygen only below $723 \mathrm{~K}$. Above $723 \mathrm{~K}$ the $\mathrm{Mo}_{5} \mathrm{O}_{14}$-type structure of $(\mathrm{MoV})_{5} \mathrm{O}_{14}$ slowly decomposed and was oxidized into a $\mathrm{MoO}_{3}$-type structure.

\section{In situ XAS}

Very similar Mo $\mathrm{K}$ near-edge spectra of $(\mathrm{MoVW})_{5} \mathrm{O}_{14}$ and $(\mathrm{MoV})_{5} \mathrm{O}_{14}$ are indicative of molybdenum centers in a similar local structural coordination in both materials. The same holds for the local structure around the $\mathrm{V}$ centers in $(\mathrm{MoVW})_{5} \mathrm{O}_{14}$ and $(\mathrm{MoV})_{5} \mathrm{O}_{14}(\mathrm{Fig}-$ ure 4). Compared to the $\mathrm{V} \mathrm{K}$ edge spectra of $\mathrm{VO}_{2}$ and $\mathrm{V}_{2} \mathrm{O}_{5}$

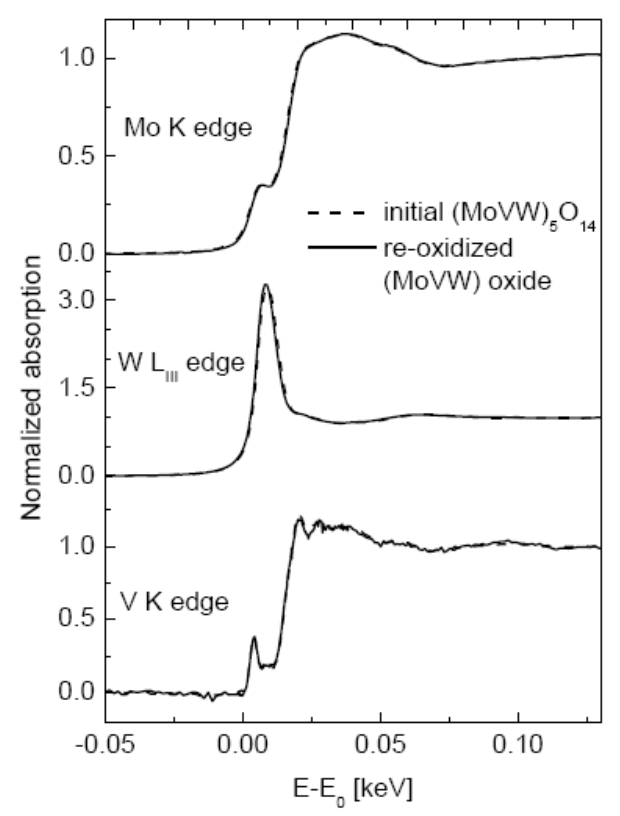

Figure 3: XANES spectra measured at the Mo $\mathrm{K}$ edge, $\mathrm{W} \mathrm{L}_{\mathrm{III}}$ edge, and $\mathrm{V} \mathrm{K}$ edge of initial $(\mathrm{MoVW})_{5} \mathrm{O}_{14}$ and re-oxidized (MoVW) oxide. 


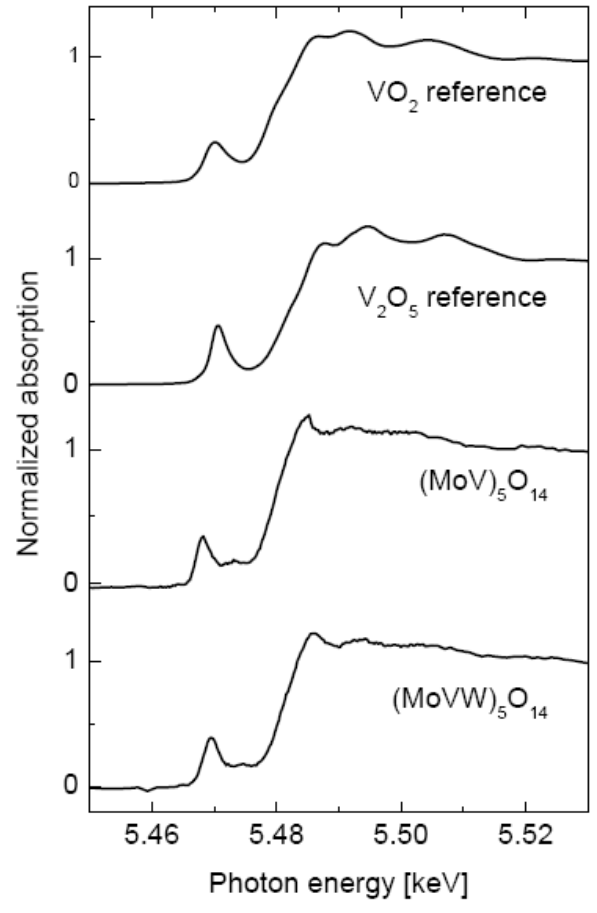

Figure 4: XANES spectra taken at $\mathrm{V} \mathrm{K}$ edge of the initial $(\mathrm{MoVW})_{5} \mathrm{O}_{14}$ and $(\mathrm{MoV})_{5} \mathrm{O}_{14}$ compared to references $\mathrm{VO}_{2}$ and $\mathrm{V}_{2} \mathrm{O}_{5}$.

references, the average valence of the $\mathrm{V}$ centers in $(\mathrm{MoVW})_{5} \mathrm{O}_{14}$ and $(\mathrm{MoV})_{5} \mathrm{O}_{14}$ amounts to about 4.5. Nearedge spectra at the Mo $\mathrm{K}, \mathrm{V} \mathrm{K}$, and $\mathrm{W}_{\mathrm{III}}$ edges of the initial $(\mathrm{MoVW})_{5} \mathrm{O}_{14}$ are shown in Figure 3. Moreover, Figure 3 depicts the near-edge spectra of the $(\mathrm{MoVW})_{5} \mathrm{O}_{14}$ material obtained after a cycle of reduction in propene and re-oxidation at $773 \mathrm{~K}$. Apparently, a similar local and electronic structure of all metal centers is found in the initial and the re-oxidized (MoVW) $)_{5} \mathrm{O}_{14}$ material. Conversely, the Mo K (Figure 5) and V K near-edge spectra of the initial $(\mathrm{MoV})_{5} \mathrm{O}_{14}$ and the re-oxidized material indicate a different local structure around the molybdenum and vanadium centers. Moreover, compared to the spectrum of a $\mathrm{MoO}_{3}$ reference (Figure 5), the Mo centers in the $\mathrm{MoO}_{3}$-type structure of the re-oxidized (MoV) oxide exhibit a slightly reduced average valence $(\sim 5.8)$ and a different local structure. The latter maybe due to the incorporation of vanadium centers in the $\mathrm{MoO}_{3}$-type structure. Furthermore, XRD analysis of the material obtained from re-oxidizing the $(\mathrm{MoV})$ dioxide yielded a minor amount of a mixed $\mathrm{Mo}_{\mathrm{x}} \mathrm{V}_{2-\mathrm{x}} \mathrm{O}_{5}$ phase (e.g. $0.5 \% \mathrm{Mo}_{0.56} \mathrm{~V}_{1.44} \mathrm{O}_{5}$ ICSD [24338]).

Mo centers in the as-prepared $(\mathrm{MoVW})_{5} \mathrm{O}_{14}$ and $(\mathrm{MoV})_{5} \mathrm{O}_{14}$ materials exhibited an average valence of less than $6(\sim 5.8)$. A similarly reduced average valence was observed for the Mo centers in the $\mathrm{Mo}_{5} \mathrm{O}_{14}$-type structure obtained from re-oxidizing the (MoVW) dioxide. Conversely, the Mo centers in the $\mathrm{MoO}_{3}$-type structure obtained from re-oxidizing the $(\mathrm{MoV})$ dioxide exhibit an average valence of about 6 (Figure 5). The local structure and the average valence of the Mo centers in the (MoVW)

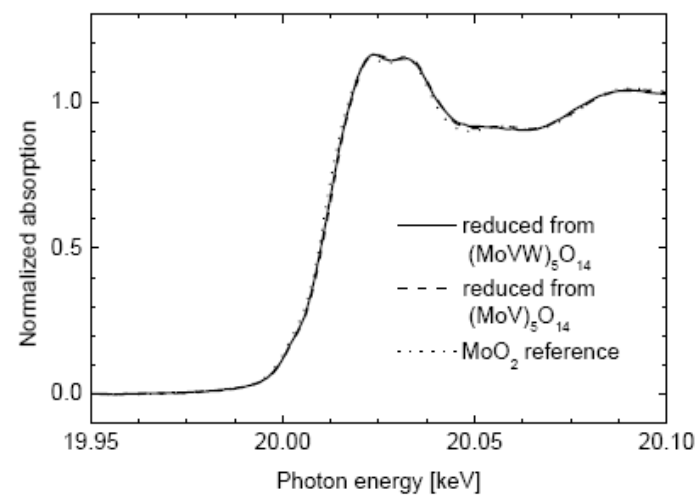

Figure 5: XANES spectra taken at the Mo $\mathrm{K}$ edge of re-oxidized $(\mathrm{MoV})$ oxide after reduction in $10 \%$ propene compared to a $\mathrm{MoO}_{3}$ reference.

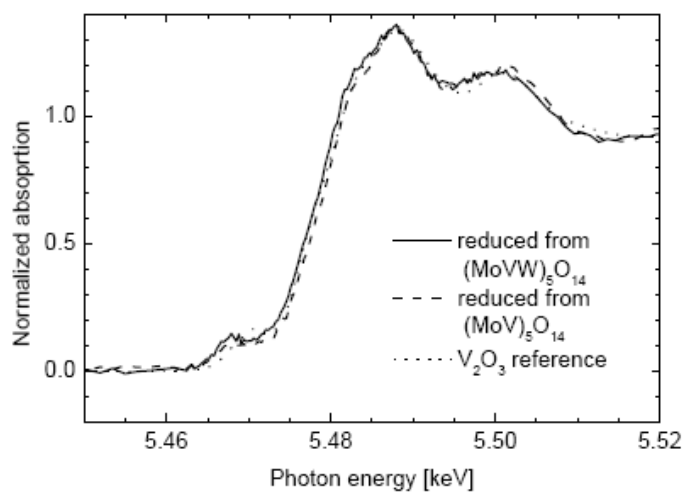

Figure 6: XANES spectra of (MoVW) oxide and (MoV) oxide at the Mo $\mathrm{K}$ edge after reduction in $10 \%$ propene compared to a $\mathrm{MoO}_{2}$ reference.

dioxide and the (MoV) dioxide were similar to those of the Mo centers in $\mathrm{MoO}_{2}$ (Figure 6). Slight differences are indicative of the incorporation of $\mathrm{V}$ and $\mathrm{W}$ in the corresponding $\mathrm{MoO}_{2}$-type structures. The V K near-edge spectra of the dioxides obtained from reducing the corresponding $\mathrm{Mo}_{5} \mathrm{O}_{14}$-type oxides in propene at $773 \mathrm{~K}$ are depicted in Figure 7. Apparently, the average valance and the local structure of the $\mathrm{V}$ centers in the dioxide materials is similar to those of the $\mathrm{V}$ centers in $\mathrm{V}_{2} \mathrm{O}_{3}$.

Mo $\mathrm{K}$ near-edge spectra measured during temperature programmed treatment of $(\mathrm{MoVW})_{5} \mathrm{O}_{14}$ and $(\mathrm{MoV})_{5} \mathrm{O}_{14}$ in $10 \%$ propene showed an onset of transformation into a $\mathrm{MoO}_{2}$-type structure at a temperature of $685 \mathrm{~K}$. Conversely, $\mathrm{V} \mathrm{K}$ and $\mathrm{W} \mathrm{L}_{\text {III }}$ near-edge spectra measured during treatment of $(\mathrm{MoVW})_{5} \mathrm{O}_{14}$ and $(\mathrm{MoV})_{5} \mathrm{O}_{14}$ in $10 \%$ propene exhibited an onset of structural changes at $\sim 650 \mathrm{~K}$. In particular, a decrease in the characteristic V K pre-edge peak height at $\sim 650 \mathrm{~K}$ was observed. This is indicative of an onset of reduction of the $\mathrm{V}$ centers in the $\mathrm{Mo}_{5} \mathrm{O}_{14}$-type structures prior to a detectable reduction of the Mo centers. The detailed EXAFS analysis of the structural changes occurring during thermal treatment of the $\mathrm{Mo}_{5} \mathrm{O}_{14}$-type materials is underway. 


\section{Discussion}

\subsection{Influence of vanadium on electronic and geometric structure}

Partially reduced vanadium centers in selective oxidation catalysts are assumed to enhance the hydrogen abstraction from hydrocarbon reactants. Accordingly, in the $\mathrm{Mo}_{5} \mathrm{O}_{14}$-type metal oxides investigated, the $\mathrm{V}$ centers exhibit an average valence of less than 5 (Figure 4). During thermal treatment under reducing conditions, the $\mathrm{V}$ centers are reduced prior to the Mo or $\mathrm{W}$ centers. This may be in agreement with a participation of the $\mathrm{V}$ centers in the active site of $\mathrm{Mo}_{5} \mathrm{O}_{14}$-type catalysts for selective oxidation. Conversely, the $\mathrm{W}$ centers in the mixed oxide catalysts may rather play a structural role than being involved in the catalytic cycle. The (MoVW) dioxide and (MoV) dioxide obtained from reduction of the $\mathrm{Mo}_{5} \mathrm{O}_{14}$-type materials exhibit a reduced average valence of the $\mathrm{V}$ centers (Figure 7) compared the Mo centers (Figure 6). This is in agreement with previous reports on the average valence of $\mathrm{V}$ centers in vanadium oxides doped with up to $10 \%$ molybdenum [22]. There, the authors did not detect changes in the Mo average valence but reduction of vanadium to preserve electro neutrality of the materials.

The long-range structural data presented indicate an influence of the $\mathrm{V}$ centers on the geometric structure of the $\mathrm{Mo}_{5} \mathrm{O}_{14}$-type materials studied. (MoVW) $)_{5} \mathrm{O}_{14}$ and $(\mathrm{MoV})_{5} \mathrm{O}_{14}$ were prepared with different amounts of vanadium (i.e. $23 \%$ and $9 \%$ ). Accordingly, a decrease in the lattice constants (Table 1) and the volume of the unit cell was found with an increasing $\mathrm{V}$ content. Moreover, the distortion of the dioxide phases obtained from reduction of the $\mathrm{Mo}_{5} \mathrm{O}_{14}$-type materials from the nearly rutile type $\mathrm{MoO}_{2}$ also increases with increasing $\mathrm{V}$ content (Table 2). In agreement with Vegard's law, the smaller size of the vanadium centers compared to Mo and $\mathrm{W}$ results in a reduced unit cell volume of the mixed oxides. Hence, (MoVW) dioxide possesses a smaller unit cell volume than (MoV) dioxide.

\subsection{Stabilizing effect of tungsten in Mo5014- type structures}

$(\mathrm{MoV})_{5} \mathrm{O}_{14}$ and $(\mathrm{MoVW})_{5} \mathrm{O}_{14}$ were transformed into a monoclinic $\mathrm{MoO}_{2}$-type phase (Figure 1 and Figure 2) during thermal treatment under reducing conditions (10\% propene) at about $670 \mathrm{~K}$ and $720 \mathrm{~K}$, respectively. During treatment under oxidizing conditions (20\% oxygen), the $\mathrm{Mo}_{5} \mathrm{O}_{14}$-type structure of $(\mathrm{MoVW})_{5} \mathrm{O}_{14}$ was stable at 773 $\mathrm{K}$. Conversely, the $(\mathrm{MoV})_{5} \mathrm{O}_{14}$ material slowly undergoes a phase transformation into $\mathrm{MoO}_{3}$-type material starting at $723 \mathrm{~K}$. Apparently, the $(\mathrm{MoVW})_{5} \mathrm{O}_{14}$ material exhibited a higher stability under reducing and oxidizing conditions compared to the tungsten-free $(\mathrm{MoV})_{5} \mathrm{O}_{14}$ material. The onset temperature of the transformation of $(\mathrm{MoV})_{5} \mathrm{O}_{14}$ in oxygen into the $\mathrm{MoO}_{3}$-type structure is close to the onset

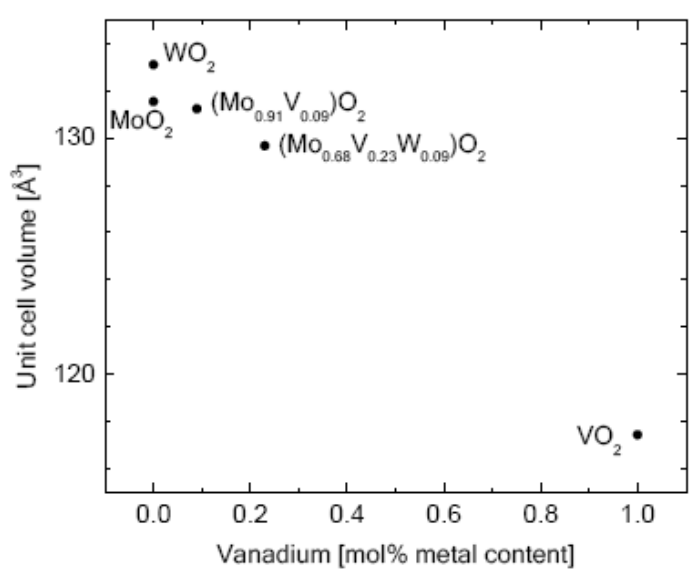

Figure 7: XANES spectra of (MoVW) oxide and (MoV) oxide at the $\mathrm{V} \mathrm{K}$ edge after reduction in $10 \%$ propene compared to a $\mathrm{V}_{2} \mathrm{O}_{3}$ reference.

Table 2: Lattice constants from XRD refinement of monoclinic (MoVW) dioxide and (MoV) dioxide based on ICSD [23722]

\begin{tabular}{|l|l|l|}
\hline & $($ MoV) dioxide & (MoVW) dioxide \\
\hline $\mathrm{a}[\AA]$ & 5.69 & 5.63 \\
\hline $\mathrm{b}[\AA]$ & 4.79 & 4.84 \\
\hline $\mathrm{c}[\AA]$ & 5.56 & 5.61 \\
\hline$\beta\left[^{\circ}\right]$ & 121.17 & 121.00 \\
\hline
\end{tabular}

temperature of the reduction of $(\mathrm{MoV})_{5} \mathrm{O}_{14}$ in propene. On the one hand, the oxygen mobility in the oxide materials is a prerequisite for both, reduction to the $\mathrm{MoO}_{2}$-type phase and oxidation to the $\mathrm{MoO}_{3}$-type phase. On the other hand, tungsten in the $(\mathrm{MoVW})_{5} \mathrm{O}_{14}$ material stabilizes the $\mathrm{Mo}_{5} \mathrm{O}_{14}$-type structure and prevents complete oxidation, even under conditions of sufficient oxygen mobility and a high oxidation potential of the gas phase.

The stabilizing and structure directing effect of tungsten in the (MoVW) oxide is particularly apparent in the re-oxidation behavior of the corresponding (MoVW) dioxide. The tungsten centers in the $\mathrm{MoO}_{2}$-type material obtained from reducing $(\mathrm{MoVW})_{5} \mathrm{O}_{14}$ exert a strong structure-directing effect under oxidizing conditions. Eventually, re-oxidation of the (MoVW) dioxide leads to the reformation of the $\mathrm{Mo}_{5} \mathrm{O}_{14}$ structure. It has been frequently reported, that the $\mathrm{Mo}_{5} \mathrm{O}_{14}$-type structure can be obtained from thermal treatment of suitable molecular mixed metal precursors [14]. The corresponding reaction proceeds through a series of polycondensation steps resulting in the three-dimensional $\mathrm{Mo}_{5} \mathrm{O}_{14}$ structure. Here we have shown for the first time that it is possible to transform the tetragonal $(\mathrm{MoVW})_{5} \mathrm{O}_{14}$ material into a monoclinic $\mathrm{MoO}_{2}$-type structure, and to then re-oxidize the (MoVW) dioxide into the $\mathrm{Mo}_{5} \mathrm{O}_{14}$-type structure. This striking ability is most likely due to the single cation position in the monoclinic structure which does not provide a driving force for further cation rearrangement. Further structural studies on the un- 
derlying mechanism of this solid-gas reaction are underway.

Similar to our $(\mathrm{MoVW})_{5} \mathrm{O}_{14}$ material, the reduction and re-oxidation properties of a $(\mathrm{MoVNb})_{5} \mathrm{O}_{14}$ system as a suitable model catalyst have been recently discussed [23]. The $(\mathrm{MoVW})_{5} \mathrm{O}_{14}$ material studied here combines suitable redox properties with a sufficient catalytic performance [24]. Therefore, it can be used as a model system for the redox behavior of the more complex MoVTeNb oxides applied in the selective oxidation of propane.

\section{Summary}

Bulk structural properties and stabilities of crystalline single phase $\left(\mathrm{Mo}_{0.91} \mathrm{~V}_{0.09}\right)_{5} \mathrm{O}_{14}$ and $\left(\mathrm{Mo}_{0.68} \mathrm{~V}_{0.23} \mathrm{~W}_{0.09}\right)_{5} \mathrm{O}_{14}$ phases were investigated under reducing and oxidizing reaction conditions. A stabilizing effect of tungsten in the $(\mathrm{MoVW})_{5} \mathrm{O}_{14}$ sample under oxidizing conditions was found. Additionally, tungsten centers in

\section{References}

1. G. Mestl, Ch. Linsmeier, R. Gottschall, M. Dieterle, J. Find, D. Herein, J. Jäger, Y. Uchida, R. Schlögl, Journal of Molecular Catalaysis A: Chemical 162, (2000) 463

2. M. Dieterle, G. Mestl, J. Jäger, Y. Uchida, H. Hibst, R. Schlögl, Journal of Molecular Catalysis A: Chemical 174 (2001) 169

3. S. Breiter, M. Estenfelder, H.-G. Lintz, A. Tenten, H. Hibst, Applied Catalysis A 134 (1996) 81

4. O. Ovsitser, Y. Uchida, G. Mestl, G. Weinberg, A. Blume, J. Jäger, M. Dieterle, H. Hibst, R. Schlögl, Journal of Molecular Catalysis A 185 (2002) 291

5. V. M. Bondareva, T. V. Andrushkevich, G. I. Aleshina, L. M. Plyasova, L. S. Dovlitova, O. B. Lapina, D. F. Khabibulin, A. A. Vlasov, React. Kinet. Catal. Lett. 87, 2 (2006) 377

6. Peter De Santo, Douglas J. Buttrey, Robert K. Graselli, Claus G. Lugmair, Anthony, F. Volpe, Brian H. Toby, Thomas Vogt, Topics in Catalysis Vol. 23, 1-4 (2003)

7. L. Kihlborg, Arkiv Kemi 21, 40 (1963) 427

8. N. Yamazoe, L. Kihlborg, Acta Cryst. B 31 (1975) 1666

9. T. Ekström, M. Nygren, Acta Chem. Scand. 26 (1972) 1827

10. T. Ekström, Acta Chem. Scand. 26 (1972) 1843 a (MoVW) dioxide material obtained from reducing $(\mathrm{MoVW})_{5} \mathrm{O}_{14}$ exert a pronounced structure-directing effect under re-oxidation conditions. The effect of tungsten centers on the particular bulk structural properties of $(\mathrm{MoVW})_{5} \mathrm{O}_{14}$ may account for the structural promoting effect of tungsten in selective oxidation.

\section{Acknowledgement}

HASYLAB/Hamburg is acknowledged for providing beamtime for this work.
11. T. Ekström, Materials Research Bulletin 7 (1972) 19

12. T. Ekström, M. Nygren, Acta Chemica Scandinavica 26, 5 (1972) 1836

13. L. Kihlborg, Acta Chem. Scand. 23 (1969) 1834

14. S. Knobl, G. A. Zenkovets, G. N. Kryukova, O. Ovsitser, D. Niemeyer, R. Schlögl, G. Mestl, Journal of Catalysis 215 (2003) 177

15. DIFFRAC plus Evaluation Package release (2003)

16. TOPAS Version 2.1 Bruker AXS

17. Inorganic Crystal Structure Database, Fachinformationszentrum (FIZ) Karlsruhe, Germany

18. T. Ressler, J. Synchrotron Rad. 5 (1998) 118

19. J. Wong, F. W. Lytle, R. P. Messmer, D. H. Maylotte, Phys. Rev. B 30, 10 (1984) 5596

20. T. Ressler, J. Wienold, R.E. Jentoft, T. Neisius, Journal of Catalysis 210 (2002) 67

21. E. Rödel, R. Schlögl, T. Ressler, in preparation.

22. F. Haaß, A. H. Adams, T. Buhrmester, G. Schimanke, M. Martin, H. Fuess, PCCP 5 (2003) 4317

23. M. Roussel, M. Bouchard, E. Bordes-Richard, K. Karim, S. Al-Sayari, Cat. Today 99, 1-2 (2005) 77

24. E. Rödel, S. Knobl, R. Schlögl, T. Ressler; in preparation 